ABREU, Jacqueline de Souza. Conceitos de valor, interpretação, direito e política: críticas de Bernard Williams a Ronald Dworkin. Revista Eletrônica Direito e Política, Programa de Pós-Graduação Stricto Sensu em Ciência Jurídica da UNIVALI, Itajaí, v.13, n.2, 20 quadrimestre de 2018. Disponível em: www.univali.br/direitoepolitica - ISSN 1980-7791

\title{
LIBERDADE DE EXPRESSÃO PUBLICADA VERSUS ANONIMATO: A (IR)RESPONSABILIZAÇÃO NO CYBERBULLYING
}

\author{
LIBERTY OF SPEECH VERSUS ANONYMITY: THE (UNDER)DETERRENCE OF \\ CYBERBULLYNG
}

\author{
Thami Covatti Piaia ${ }^{1}$ \\ Letícia Mousquer Ritter ${ }^{2}$ \\ Rafael Martins Sangoi ${ }^{3}$
}

SUMÁRIO: Introdução; 1 Haters, Cyberbullying e Anonimato; 2 Direito Digital e Responsabilidade no Brasil; 3 A Internet e a Positivação das Condutas no Direito Norte-Americano; Considerações Finais; Referência das fontes citadas.

\section{RESUMO}

A internet trouxe à vida das pessoas um novo espaço democrático de representação de direitos e deveres. Entretanto, a infindável gama de possibilidades interativas propiciada pela internet, resultou nas mais diferentes manifestações do pensamento dos usuários da rede, cujas opiniões são publicadas, sejam elas positivas ou negativas. Nesse contexto, o objetivo do presente trabalho consiste em estudar a necessidade de responsabilização dos internautas quando utilizam a internet para a prática do cyberbullying (intimidação sistemática praticada via internet), afinal, a internet não pode ser considerada um espaço sem representação de direitos e deveres. O método de abordagem a ser seguido será o empírico-dialético, com revisão de literatura e análise descritiva dos fenômenos pesquisados. Em conclusão, aponta-se para a necessidade da determinação de parâmetros que permitam a responsabilização dos praticantes desses atos a fim de salvaguardar o equilíbrio entre direitos fundamentais.

Palavras-chave: Liberdade de Expressão Publicada; Anonimato; Haters; Cyberbullying.

\footnotetext{
${ }^{1}$ Doutora em Direito pela Universidade Federal do Rio Grande do Sul - UFRGS. Visiting Scholar na Universidade de Illinois - Campus de Urbana-Champaign - EUA (2012). Professora na Graduação e no Programa de Pós-Graduação Stricto Sensu em Direito, Mestrado e Doutorado da Universidade Regional Integrada do Alto Uruguai e das Missões - URI -, Campus de Santo Ângelo/RS. Coordenadora do Projeto de Pesquisa: novas formas de proteção dos direitos culturais e do patrimônio cultural: aproximação entre direito, inovação e política. Membro do Grupo de Pesquisa Conflito, Cidadania e Direitos Humanos. Santo Ângelo/RS/Brasil.

2 Doutora em Direito pela Universidade do Vale dos Sinos - UNISINOS. Professora na Graduação em Direito da Universidade Regional Integrada do Alto Uruguai e das Missões - URI, Campus de Santo Ângelo/RS. Membro do Projeto de Pesquisa: novas formas de proteção dos direitos culturais e do patrimônio cultural: aproximação entre direito, inovação e política e do Grupo de Pesquisa: Conflito, Cidadania e Direitos Humanos. Advogada. Santo Ângelo/RS/Brasil.

3 Mestrando em Direito no Programa de Pós-Graduação Stricto Sensu em Direito, Mestrado e Doutorado da Universidade Regional Integrada do Alto Uruguai e das Missões - URI -, Campus de Santo Ângelo/RS.
} 
ABREU, Jacqueline de Souza. Conceitos de valor, interpretação, direito e política: críticas de Bernard Williams a Ronald Dworkin. Revista Eletrônica Direito e Política, Programa de Pós-Graduação Stricto Sensu em Ciência Jurídica da UNIVALI, Itajaí, v.13, n.2, $2^{\circ}$ quadrimestre de 2018. Disponível em: www.univali.br/direitoepolitica - ISSN 1980-7791

\section{ABSTRACT}

The internet has brought to people's lives a new democratic space for the representation of rights and duties. However, the endless range of interactive possibilities provided by the internet has resulted in the most different manifestation of the thoughts of network users, whose opinions are published, whether positive or negative. In this context, the objective of the present work is to study the need to promote accountability of Internet users when using the Internet to practice cyberbullying (systematic intimidation practiced via the Internet), after all, the Internet cannot be considered as a space without representation rights and duties. The method of approach to be followed will be the empiric-dialectic, with literature review and descriptive analysis of the phenomena researched. In conclusion, it is pointed out to the necessity of the determination of parameters that allow the accountability of the practitioners of these acts in order to safeguard the balance between fundamental rights.

Keywords: Published Freedom of Speech; Anonymity; Haters; Cyberbullying.

\section{INTRODUÇÃO}

A internet modificou a maneira de trabalhar, viajar, consumir, atualizar conhecimentos, criando assim, novas formas de interações, bem como trazendo mudanças na forma de manifestação da expressão dos usuários. De certa forma, a vida tornou-se mais célere e prática depois da aproximação das pessoas com as novas tecnologias, especialmente a internet.

No entanto, embora sejam muitos os aspectos positivos, a utilização da rede também trouxe elementos negativos. Velhos delitos, como o estelionato, a exploração sexual, o plágio e a difamação, foram recodificados pela internet passando à denominação de crimes cibernéticos comuns, na medida em que utilizam a internet apenas como instrumento para a realização de um delito já tipificado pela lei penal.

Igualmente, através da internet, surgiram conflitos que há menos de dez anos não existiam, classificados em crimes cibernéticos puros ${ }^{4}$ (tais como a invasão de computadores por hackers e a criação e compartilhamento de vírus eletrônicos);

\footnotetext{
4 Crimes cibernéticos puros podem ser definidos como "toda e qualquer conduta ilícita que tenha por objetivo exclusivo o sistema de computador, seja pelo atentado físico ou técnico do equipamento e seus componentes, inclusive dados e sistemas". COSTA, Marco Aurélio Rodrigues. Crimes de Informática. Disponível em: <http://www.jus.com.br/doutrina/crinfo.html. >. Acesso em: 05 jul. 2018.
} 
ABREU, Jacqueline de Souza. Conceitos de valor, interpretação, direito e política: críticas de Bernard Williams a Ronald Dworkin. Revista Eletrônica Direito e Política, Programa de Pós-Graduação Stricto Sensu em Ciência Jurídica da UNIVALI, Itajaí, v.13, n.2, $2^{\circ}$ quadrimestre de 2018. Disponível em: www.univali.br/direitoepolitica - ISSN 1980-7791

crimes cibernéticos mistos ${ }^{5}$ (por exemplo: transferências ilícitas de valores em uma home-banking, clonagem de documentos eletrônicos, cyberbullying), e crimes cibernéticos próprios ${ }^{6}$ (tais como: invasão de sistemas para modificar, alterar, inserir dados falsos, dentre outros).

Entre todas as classificações dos crimes cibernéticos, observa-se que o massivo cometimento destes, esconde-se sobre o manto do anonimato. Publicações anônimas e a ocultação por trás de identidades on line são fatores que podem ser traduzidos na confiança do agente de que não haverá confronto físico com a vítima. Com isso, a problemática do presente trabalho retoma a discussão sobre o anonimato, que atualmente assume elevado patamar visto que não envolve apenas a existência de autoria em publicações, mas também tem implicações na proteção de direitos da personalidade, como integridade física, honra, liberdade, vida privada, intimidade e imagem, especialmente, em se tratando do crime de cyberbullying, uma espécie de bullying virtual cujos ataques se propagam rapidamente, e em poucos instantes atingem uma plateia de proporções incomensuráveis.

Os propagadores dos discursos de ódio nos crimes virtuais são conhecidos como haters e costumam se esconder por trás de suas identidades on line, pois geralmente são pessoas demasiadamente inibidas no contato pessoal, fato que desaparece quando estão conectados, somando-se à dificuldade que reside no tempo para que as mensagens publicadas possam ser retiradas da web, o cyberbullying causa danos imensuráveis à vítima, já que em segundos, milhares de pessoas podem ter acesso a referidas informações.

\footnotetext{
5 Crimes cibernéticos mistos "são aqueles em que o uso da internet ou sistema informático é condição sine qua non para a efetivação da conduta, embora o bem jurídico visado seja diverso ao informático". PINHEIRO, Reginaldo César. Os cybercrimes na esfera jurídica brasileira. Disponível em:<http://jus.com.br/revista/texto/1830/os-cybercrimes-na-esfera-juridicabrasileira>. Acesso em: 05 jul. 2018.

${ }^{6}$ Crimes cibernéticos próprios são aqueles que em que o sistema informático do sujeito passivo é o objeto e o meio do crime, "São aqueles em que o bem jurídico protegido pela norma penal é a inviolabilidade das informações automatizadas (dados).". VIANA, Marco Túlio apud CARNEIRO, Adeneele Garcia. Fundamentos de direito penal informático. Do acesso não autorizado a sistemas computacionais. Rio de Janeiro: Forense, 2003, p. 13-26.
} 
ABREU, Jacqueline de Souza. Conceitos de valor, interpretação, direito e política: críticas de Bernard Williams a Ronald Dworkin. Revista Eletrônica Direito e Política, Programa de Pós-Graduação Stricto Sensu em Ciência Jurídica da UNIVALI, Itajaí, v.13, n.2, $2^{\circ}$ quadrimestre de 2018. Disponível em: www.univali.br/direitoepolitica - ISSN 1980-7791

Demonstra-se a importância de se pensar sobre a responsabilização dos agentes propagadores do cyberbullying na sociedade atual, cada vez mais adepta às novas tecnologias, bem como a repercussão desses atos, afetando de forma negativa, o cotidiano dos cidadãos usuários de internet no Brasil e no mundo. Assim, o objetivo específico do presente trabalho consiste estudar a necessidade de responsabilização dos haters na prática do cyberbullying como forma de tornar a internet um espaço de representação de direitos e deveres. A justificativa do assunto se dá na medida em que no Brasil há escassez de estudos voltados para a análise do direito à privacidade e à proteção dos dados ${ }^{7}$.

Tendo em vista que livre manifestação da expressão assumiu papel de destaque no Direito Digital brasileiro, a pesquisa assenta-se na hipótese que, a fim de salvaguardar o equilíbrio normativo e a harmonia social, há necessidade de discussão sobre liberdade de expressão publicada, especialmente quando confrontada com os demais direitos fundamentais.

Para tanto, incialmente, serão trabalhados os marcos conceituais acerca da terminologia empregada ao problema, oportunidade em que será demonstrada a incidência de tais conceitos em casos reais sobre o tema. No segundo momento será abordado como o Direito Digital e responsabilidade dos internautas vem se desenvolvendo no Brasil. Por fim, o item final do texto abordará um estudo comparativo do tratamento dado ao anonimato no direito norte-americano.

\section{HATERS, CYBERBULLYING E ANONIMATO}

Hater é uma palavra inglesa que, em tradução livre significa: "o que odeia" ou "odiador", tendo se popularizado na internet para classificar as pessoas que praticam bullying virtual ou cyberbullyng. Por ter se tornado uma conduta frequente, esse tipo de internauta foi batizado simplesmente de "hater". Os haters são usuários de internet que objetivam um determinado tema ou uma pessoa, que será alvo de ataques, podendo essa agressão vir de várias maneiras, mas

\footnotetext{
7 BOFF, Salete; FORTES, Vinícius Borges. A Privacidade e a Proteção dos Dados Pessoais no Ciberespaço como um Direito Fundamental: perspectivas de construção de um marco regulatório para o Brasil. Sequência (Florianópolis), n. 68, p. 109-127, jun. 2014, p. 111.
} 
ABREU, Jacqueline de Souza. Conceitos de valor, interpretação, direito e política: críticas de Bernard Williams a Ronald Dworkin. Revista Eletrônica Direito e Política, Programa de Pós-Graduação Stricto Sensu em Ciência Jurídica da UNIVALI, Itajaí, v.13, n.2, $2^{\circ}$ quadrimestre de 2018. Disponível em: www.univali.br/direitoepolitica - ISSN 1980-7791

geralmente as provocações são feitas por comentários públicos ou mensagens privadas, posteriormente compartilhadas.

A ação por eles perpetrada é conhecida como bullying virtual ou cyberbullying e consiste no tipo de ataque on line mais nocivo que existe, dada à forma como ele se aproveita da insegurança e das vulnerabilidades de suas vítimas, causando humilhação e danos psicológicos. Para Kimberly L. Mason, ${ }^{8}$ o cyberbullying é definido como uma pessoa ou um grupo de pessoas utilizando intencionalmente informações e comunicações por meios eletrônicos para facilitar o assédio deliberado e repetido contra determinado indivíduo ou grupo de indivíduos.

O bullying se caracteriza por ações repetitivas de agressão física e/ou verbal em uma relação desigual de poder, com a clara intenção de prejudicar uma pessoa ou um grupo. O cyberbullying é a prática da crueldade on line. Com o rápido desenvolvimento da tecnologia, os autores de cyberbullying passaram a criar muitas outras formas de atormentar suas vítimas. É mais terrível do que o bullying, porque a perseguição é implacável, podendo chegar a 24 horas por dia nos sete dias da semana. A pessoa é atacada por mensagens de texto ou de voz no celular, filmada ou fotografada secretamente em situações constrangedoras que podem ser colocadas na rede. $\mathrm{O}$ autor pode criar um perfil falso da vítima em sites de relacionamento para difamá-la ou adulterar fotos em que, por exemplo, ela aparece como garota de programa, com seu celular divulgado pelas listas de contato do autor e de seus amigos. ${ }^{9}$

Conforme Jennifer D'auria, a questão deve ser vista como um problema de saúde pública global, uma vez que atinge crianças, adolescentes e adultos, no mundo inteiro, tendo, muitas vezes, consequências negativas para as vítimas, podendo, inclusive, levar ao suicídio. ${ }^{10}$ No cyberbullying, diferentemente do bullying tradicional, os ataques podem ser feitos sem a característica da repetição, em razão da rapidez da propagação da mensagem que em poucos minutos atinge uma

8 MASON, K. L. Cyberbullying: A Preliminary Assessment for School Personnel. Psychology in the Schools, v. 45, n. 4. p. 323, 2008.

9 MALDONADO, Maria Tereza. Bullying e Cyberbullying: o que fazemos com o que fazem conosco? São Paulo: Moderna, 2011, p. 37.

10 D'AURIA, Jennifer. Cyberbullying Resources for Youth and Their Families. Journal of Pediatir Health Care, v. 28, n. 2, p. e19, 2014. 
ABREU, Jacqueline de Souza. Conceitos de valor, interpretação, direito e política: críticas de Bernard Williams a Ronald Dworkin. Revista Eletrônica Direito e Política, Programa de Pós-Graduação Stricto Sensu em Ciência Jurídica da UNIVALI, Itajaí, v.13, n.2, $2^{\circ}$ quadrimestre de 2018. Disponível em: www.univali.br/direitoepolitica - ISSN 1980-7791

plateia de proporções incomensuráveis, potencializando dramaticamente seus efeitos, que podem ser devastadores e até mesmo fatais.

Danielle Citron, especialista em crimes cometidos na internet, compara o padrão de comportamento dos haters a grupos mascarados como a Ku Klux Klan, ${ }^{11}$ já que os haters costumam se esconder por trás de suas identidades on line, sendo pessoas normalmente inibidas no contato pessoal, fato que desaparece quando estão na internet, ocasião em que deixam transparecer a sua face oculta. ${ }^{12}$ Sua intenção é exercer alguma forma de poder e elevar seu status social por meio da humilhação de outras pessoas, especialmente aquelas consideradas mais fracas ou possivelmente ameaçadoras. Eles podem realizar publicações anônimas, se ocultar por trás de identidades on line ou até usar suas identidades verdadeiras com a confiança de que provavelmente não serão confrontados fisicamente pela vítima.

Basicamente o hater é uma pessoa que não aprendeu a transformar sua raiva em diálogo e para quem o sofrimento do outro não é motivo para deixar de agir. Ao contrário, sente satisfação com a reação do agredido, supondo ou antecipando quão dolorosa será aquela crueldade vivida pela vítima. ${ }^{13}$ É uma pessoa que simplesmente não está feliz ou satisfeita com o êxito, conquista ou felicidade de outra pessoa. Assim sendo, prefere atacar e criticar virtualmente o indivíduo, expondo-o a situações comprometedoras publicamente sobre essa pessoa, ou desvalorizando as ações e vitórias do outro.

O hater pratica o ato de odiar alguma coisa ou alguém, e, esta expressão, não está diretamente relacionada com a inveja, pois os haters nem sempre desejam ser ou possuir algo de alguém, mas sim, somente criticar e desvalorizar outra pessoa perante seu grupo social. O principal alvo dos haters são celebridades e demais figuras públicas e o palco para tanto ódio são redes sociais como Facebook,

\footnotetext{
${ }^{11}$ CITRON, Danielle Keats. Cyber Civil Rights, 89 Boston University Law Review 81.

12 MALDONADO, Maria Tereza. A Face Oculta - Uma História de Bullying e Cyberbullying. São Paulo: Saraiva, 2009, p. 17.

13 MALDONADO, Maria Tereza. A Face Oculta - Uma História de Bullying e Cyberbullying. São Paulo: Saraiva, 2009, p. 38.
} 
ABREU, Jacqueline de Souza. Conceitos de valor, interpretação, direito e política: críticas de Bernard Williams a Ronald Dworkin. Revista Eletrônica Direito e Política, Programa de Pós-Graduação Stricto Sensu em Ciência Jurídica da UNIVALI, Itajaí, v.13, n.2, $2^{\circ}$ quadrimestre de 2018. Disponível em: www.univali.br/direitoepolitica - ISSN 1980-7791

Twitter e Instagram, onde o anonimato e a facilidade de se dizer qualquer coisa acabam por popularizar o tipo social do hater.

É o que se verificou nos ataques racistas dirigidos à jornalista Maria Julia Coutinho que, em julho de 2015 foi alvo de comentários ofensivos nas redes sociais. No depoimento de um dos investigados pela participação dos ataques racistas, o depoente referiu que os agressores "se envolvem nesses crimes porque consideram a rede uma terra sem lei". ${ }^{14}$ Constatou-se também no curso da investigação, que a maioria dos perfis agressores era falso e que "logo em seguida à injuria, o perfil foi desativado". ${ }^{15}$

Fato parecido ocorreu com a filha dos atores Bruno Gagliasso e Giovanna Ewbank em novembro de 2016, quando um post fotográfico de Giovanna, na rede social Instagram, gerou o questionamento de uma seguidora acerca da adoção da filha do casal. A seguidora postou comentário racista, referindo: "Você e seu marido até que combina, mas a criança que vocês adotado não combinou muito pq ela é pretinha e lugar de preto é na África. [...] Parece uma macaquinha". ${ }^{16}$ Os pais prestaram queixa por racismo e, durante a investigação, uma menina de 14 anos confessou os ataques racistas.

O modus operandi da adolescente foi criar um perfil falso numa rede social e usar o nome e as fotos de uma suposta amiga. No depoimento à polícia, ela disse que não se preocupou com as consequências e que fez isso para zoar a amiga. A adolescente também disse à polícia que escolheu o perfil de Giovanna Ewbank de forma aleatória e que sabe que os comentários foram de cunho racista. No entanto,

14 Ministério Público ouve suspeitos de racismo contra Maria Julia Coutinho. Disponível em: <http://g1.globo.com/sao-paulo/noticia/2015/12/ministerio-publico-ouve-suspeitos-deracismo-contra-maria-julia-coutinho.html>. Acesso em 25 set 2017.

\footnotetext{
15 Ministério Público ouve suspeitos de racismo contra Maria Julia Coutinho. Disponível em: <http://g1.globo.com/sao-paulo/noticia/2015/12/ministerio-publico-ouve-suspeitos-deracismo-contra-maria-julia-coutinho.html>. Acesso em 25 set 2017.

16 Menina de 14 anos confessa ataques racistas a filha de Bruno Gagliasso. Disponível em: <http://g1.globo.com/jornal-nacional/noticia/2016/12/menina-de-14-anos-confessa-ataquesracistas-filha-e-bruno-gagliasso.html>. Acesso em 25 set. 2017.
} 
ABREU, Jacqueline de Souza. Conceitos de valor, interpretação, direito e política: críticas de Bernard Williams a Ronald Dworkin. Revista Eletrônica Direito e Política, Programa de Pós-Graduação Stricto Sensu em Ciência Jurídica da UNIVALI, Itajaí, v.13, n.2, 20 quadrimestre de 2018. Disponível em: www.univali.br/direitoepolitica - ISSN 1980-7791

o dado mais impressionante da investigação incide sobre o fato de que quando perguntada sobre sua cor, a jovem respondeu ser negra.

Criminoso episódio proporcionado pelos haters foi o jogo mortal denominado Baleia Azul, tendo se transformado em um problema mundial. A partir de um convite para uma página privada e secreta no Facebook, um instrutor passava alguns desafios aos seus novos jogadores, iniciando-se assim, a participação do internauta. A partir de então, o que parecia um jogo inocente, tornava-se macabro e mortal. No total, eram propostos 50 desafios, tais como: escrever com uma navalha na palma da mão, cortar o próprio lábio, desenhar uma baleia em seu corpo com uma faca, até chegar ao desafio final, que ordenava tirar a própria vida. Consistia em um jogo sem volta, pois após a vítima iniciar os desafios, ela não poderia desistir, pois seriam ameaçados pelos administradores do jogo, os haters.

O russo Philipp Budeikin, de 21 anos, criador do jogo de suicídio afirmou que vê suas vítimas como lixo biológico. Preso e em julgamento por incitar o suicídio de 16 garotas, confessou os crimes e disse à polícia que estava limpando a sociedade. Em seu depoimento, Budeikin afirmou que:

Começou em 2013, quando eu criei a comunidade on line. Eu estava pensando nessa ideia há cinco anos. Era necessário distinguir pessoas normais do lixo biológico. Existem pessoas e existem resíduos biológicos - aqueles que não representam nenhum valor para a sociedade, que causam ou só vão causar danos à sociedade. Eu estava limpando nossa sociedade dessas pessoas ${ }^{17}$.

Embora a conduta do hater nesse jogo seja tipificada no ordenamento jurídico brasileiro como criminosa, ${ }^{18}$ claramente se visualiza o empoderamento que o

\footnotetext{
17 Preso, criador do jogo de suicídio Baleia Azul fala em "limpeza da sociedade". Disponível em: <http://ultimosegundo.ig.com.br/mundo/2017-05-10/baleia-azul.html>. Acesso em 25 set. 2017.

18 Por exemplo, o crime cometido pelos criadores e administradores do jogo Baleia Azul é de induzimento ou instigação ao suicídio, podendo ser extensivo a qualquer um que convide ou compartilhe para outra pessoa jogar. Este ilícito se consuma quando o jogador (convidado) realiza o desafio final de tirar a própria vida. O tipo penal é o previsto no artigo 122 do Código Penal brasileiro, de induzimento, instigação ou auxílio a suicídio, com pena prevista de reclusão de dois a seis anos, podendo a pena ser duplicada caso a vítima seja menor de 18 anos (situação predominante dentre as vítimas deste jogo).
} 
ABREU, Jacqueline de Souza. Conceitos de valor, interpretação, direito e política: críticas de Bernard Williams a Ronald Dworkin. Revista Eletrônica Direito e Política, Programa de Pós-Graduação Stricto Sensu em Ciência Jurídica da UNIVALI, Itajaí, v.13, n.2, 20 quadrimestre de 2018. Disponível em: www.univali.br/direitoepolitica - ISSN 1980-7791

anonimato conferido pela internet propicia aos envolvidos em crimes cibernéticos e as redes sociais são as principais ferramentas de ataque dos haters, justamente pelo fato de que no espaço on line estes dizem ou publicam coisas que nunca teriam a coragem de dizer na vida real. O anonimato do cyberbullying favorece a sua ação, ${ }^{19}$ na medida em que os haters não estão submetidos ao julgamento direto, em face da ausência de exposição física a sua vítima, ou seja, estão protegidos pelo anonimato.

Paradoxalmente, o anonimato pode até mesmo coincidir com a manifestação da liberdade de expressão, tendo em vista que "aqueles que abraçarem opiniões impopulares com a maioria, ou mesmo uma minoria poderosa, podem preferir abrigo atrás do anonimato, seja para evitar represálias ou simplesmente para garantir que as opiniões expressadas não sejam prejudicadas com base na identidade do orador". ${ }^{20}$ Anônimo é aquele que não tem identidade, que não quer ou não pode ser reconhecido. Ele se oculta por necessidade ou por medo, mas, sobretudo, o faz poder ter uma vida "normal".

Embora nossa Carta Constitucional assegure no rol de direitos fundamentais a livre manifestação do pensamento, no mesmo rol do art. 50, no inciso IV, há a proibição do anonimato. O veto constitucional ao anonimato tem objetivo de acautelar das consequências do exercício do direito de livre expressão, é [...] essencial à própria configuração do Estado Democrático de Direito, visa-se, em última análise, a possibilitar que eventuais excessos, derivados da prática do direito à livre

19 Sobre a questão da segurança conferida pela ausência de confronto direito com as vítimas, diz o ator Bruno Mazzeo, que, por causa da interação digital nem sempre positiva, abandonou sua conta no Twitter há três anos, abdicando de uma audiência de mais de um milhão de seguidores: "Quando saio na rua, ninguém me xinga. Mas, quando olho a internet, parece que sou detestado. Eu costumava responder a algumas dessas mensagens, mas parei porque percebi que alimentava ainda mais essas pessoas. Mazzeo se recorda de uma vez em que foi ao Shopping da Gávea para almoçar e cometeu o "pecado" de não tirar os óculos escuros. Depois, quando chegou em casa, viu que um sujeito havia escrito no Twitter que ele se considerava tão famoso que nunca tirava os óculos: "O cara me viu ali, poderia ter falado comigo, mas preferiu me sacanear pela internet. Tem uma frase do Nelson Rodrigues que se aplica bem a isso: 'O grande acontecimento do século foi a ascensão espantosa e fulminante do idiota'." Disponível em: <https://oglobo.globo.com/cultura/nascidosnas-redes-sociais-os-haters-ganham-espaco-disparando-grosserias-contra-artistas-

1891325\#ixzz4tLTVMp3wstest>. Acesso em 25 set 2017.

20 ROWLAND, Diane. Privacy, Freedom of Expression and CyberSLAPPs: Fostering Anonymity on the Internet? International Review of Law Computers Carfax Publishing \&Technology, v. 17, n. 3, p. 304, nov. 2003. 
ABREU, Jacqueline de Souza. Conceitos de valor, interpretação, direito e política: críticas de Bernard Williams a Ronald Dworkin. Revista Eletrônica Direito e Política, Programa de Pós-Graduação Stricto Sensu em Ciência Jurídica da UNIVALI, Itajaí, v.13, n.2, $2^{\circ}$ quadrimestre de 2018. Disponível em: www.univali.br/direitoepolitica - ISSN 1980-7791

expressão, sejam tornados passíveis de responsabilização, a posteriori, tanto na esfera civil, quanto no âmbito penal. ${ }^{21}$

Extrai-se do inciso IV do art. $5^{\circ}$ que a liberdade de expressão de pensamento, apesar de garantida constitucionalmente, não encontra proteção quando exercida através do anonimato, em especial se esta identifica uma conduta passível de lesionar direitos de outrem. É o que frisa Celso Ribeiro Bastos:

Proíbe-se o anonimato. Com efeito, esta é a forma mais torpe e vil de emitir-se o pensamento. A pessoa que o exprime não o assume. Isto revela terrível vício moral consistente na falta de coragem. [...] mas este fenômeno é ainda mais grave. Estimula as opiniões fúteis, as meras sacadilhas, sem que o colhido por estas maldades tenha possibilidade de insurgir-se contra o seu autor, inclusive demonstrando a baixeza moral e a falta de autoridade de quem emitiu estes atos. Foi feliz, portanto, o Texto Constitucional ao coibir a expressão do pensamento anônimo. ${ }^{22}$

$\mathrm{Na}$ internet a incógnita de se localizar a autoria do cyberbullying recai sobre o nome, a imagem, o endereço físico ou virtual (e-mail) e o endereçamento ou número de IP (Internet Protocol). Todas essas características acabam por se tornar um tipo de "véu" que oculta a real identidade do autor que impossibilite a individualização do transmissor de dados. Isso porque os acessos à rede mundial de computadores são feitos com um número de IP. No entanto, é comum que um IP não seja um usuário identificável, mas sim, um acesso, o que impossibilita a identificação da pessoa que esteve na máquina naquele momento. Isso acontece nos crimes cometidos por meio de computadores públicos, como Lan Houses e Cybercafés. Além disso, os haters normalmente se utilizam de e-mails e perfis falsos.

Diante deste cenário o anonimato ganhou contornos especiais. Não é incomum que comentários ofensivos, racistas e preconceituosos sejam publicados sob um

21 CHOUKR, Fauzi Hassan. Código de Processo Penal - Comentários Consolidados e Crítica Jurisprudencial. Rio de Janeiro: Lumen Juris, 2016, p. 43.

22 BASTOS, Celso Ribeiro; MARTINS, Ives Gandra. Comentários à Constituição do Brasil. São Paulo: Saraiva: 2002, p. 44. 
ABREU, Jacqueline de Souza. Conceitos de valor, interpretação, direito e política: críticas de Bernard Williams a Ronald Dworkin. Revista Eletrônica Direito e Política, Programa de Pós-Graduação Stricto Sensu em Ciência Jurídica da UNIVALI, Itajaí, v.13, n.2, $2^{\circ}$ quadrimestre de 2018. Disponível em: www.univali.br/direitoepolitica - ISSN 1980-7791

apelido ou perfil falso, que por si só não garante o anonimato, mas dificulta a identificação da real identidade do autor.

Percebe-se que o anonimato contribui para a divulgação de inverdades e estimula a irresponsabilidade no trato com a informação. Segundo Javier Belda Iniesta e Francisco José Arenda Serna, [...] al celeridade, el anonimato y la facilidad que proporcionan las nuevas tecnologias se traducen em nuevas formas de delinquir como la difusion de programas informáticos nocivos, y en las atictividades denomindas tradicionales como las estafas comerciales. ${ }^{23}$

Para melhor compreensão do tema, far-se-á um estudo comparado no decorrer do texto, sobre a normatização do cyberbullying no Brasil e nos Estados Unidos, além das formas de responsabilização dos praticantes dessa conduta nesses países, especialmente quando configuram ataques criminosos, gerando consequências negativas para as vítimas.

\section{DIREITO DIGITAL E RESPONSABILIDADE NO BRASIL}

Quando as novas mídias foram criadas e o mundo virtual se expandiu, não existiam leis específicas para julgar casos como difamação nas redes sociais, vazamentos de fotos íntimas, pirataria, ou mesmo novos delitos, como o cyberbullying. Na medida em que a realidade virtual foi mais rápida que a realidade jurídica positivada, evidenciou-se o surgimento do Direito Digital, buscando analisar a "normatização de toda e qualquer relação em que a informática seja o fator primário, gerando direitos e deveres secundários."24

No Brasil, a normatização do Direito Digital evoluiu com a expansão da rede e, em boa parte, com a invasão do computador da atriz Carolina Dieckmann no ano de 2012. A atriz teve a caixa de e-mail violada por hackers, que publicaram na internet imagens íntimas e conversas copiadas de seu computador pessoal. $O$

23 INIESTA, Javier Belda; SERNA, Francisco José Arenda. El Paradigma de la identidade: hacia una regulación del mundo digital. Revista Forense, v. 422, p. 195, jul./dez. 2015.

24 ALMEIDA FILHO, José Carlos de Araújo. Direito Eletrônico ou Direito da Informática? Informática Pública vol. 7 (2): 11-18, 2005. Disponível em: <http://www.ip.pbh.gov.br/ANO7_N2_PDF/IP7N2_almeida.pdf>. Acesso em 22 set. 2017. 
ABREU, Jacqueline de Souza. Conceitos de valor, interpretação, direito e política: críticas de Bernard Williams a Ronald Dworkin. Revista Eletrônica Direito e Política, Programa de Pós-Graduação Stricto Sensu em Ciência Jurídica da UNIVALI, Itajaí, v.13, n.2, 20 quadrimestre de 2018. Disponível em: www.univali.br/direitoepolitica - ISSN 1980-7791

incidente acabou popularizando a Lei 12.737, sancionada em novembro daquele ano, como "Lei Carolina Dieckmann". ${ }^{25}$

A supracitada legislação promoveu alterações no Código Penal brasileiro, tipificando os delitos informáticos, criminalizando as invasões de computadores e celulares com a finalidade de copiar ou alterar dados, além de prever penas para outras áreas de responsabilidade do Direito Digital, como a violação de mecanismos de segurança para obter arquivos, perturbação de serviço telefônico ou de informações de utilidade pública e falsificação de documentos e cartões. ${ }^{26}$

Todos estes avanços com relação à normatização em Direito Digital já vinham repercutindo na legislação pátria vigente, que buscava adequar-se às novas realidades, como por exemplo, nas modificações no Estatuto da Criança e do Adolescente, feitas pela Lei 11.829/08, que buscando aprimorar o combate à produção, venda e distribuição de pornografia infantil, bem como criminalizar a aquisição e a posse de tais materiais e outras condutas relacionadas à pedofilia na internet, tipificou o crime de pornografia infantil por meio da internet. ${ }^{27}$

25 A legislação é oriunda do Projeto de Lei 2793/2011, apresentado em 29 de novembro de 2011, pelo Deputado Paulo Teixeira (PT-SP), que tramitou em regime de urgência e em tempo recorde no Congresso Nacional, em comparação com outros projetos sobre delitos informáticos que as casas de leis apreciavam como, por exemplo, o PL 84/1999, a popularizada "Lei Azeredo", também transformado em lei ordinária no. 12.735/2012 em 3 de dezembro de 2012.

26 Os delitos previstos na Lei são: 1) Art. 154-A - Invasão de dispositivo informático alheio, conectado ou não à rede de computadores, mediante violação indevida de mecanismo de segurança e com o fim de obter, adulterar ou destruir dados ou informações sem autorização expressa ou tácita do titular do dispositivo ou instalar vulnerabilidades para obter vantagem ilícita. Pena - detenção, de 3 (três) meses a 1 (um) ano, e multa. 2) Art. 266 - Interrupção ou perturbação de serviço telegráfico, telefônico, informático, telemático ou de informação de utilidade pública - Pena - detenção, de um a três anos, e multa. 3) Art. 298 - Falsificação de documento particular/cartão - Pena - reclusão, de um a cinco anos e multa.

27 Ostatuto da Criança e do Adolescente passou então a vigorar acrescido dos seguintes arts. 241-A, 241-B, 241-C, 241-D e 241-E: "Art. 241-A. Oferecer, trocar, disponibilizar, transmitir, distribuir, publicar ou divulgar por qualquer meio, inclusive por meio de sistema de informática ou telemático, fotografia, vídeo ou outro registro que contenha cena de sexo explícito ou pornográfica envolvendo criança ou adolescente: Pena - reclusão, de 3 (três) a 6 (seis) anos, e multa. § $1^{\circ}$ Nas mesmas penas incorre quem: I - assegura os meios ou serviços para o armazenamento das fotografias, cenas ou imagens de que trata o caput deste artigo; II - assegura, por qualquer meio, o acesso por rede de computadores às fotografias, cenas ou imagens de que trata o caput deste artigo. $\S 2^{\circ}$ As condutas tipificadas nos incisos I e II do $\S 1^{\circ}$ deste artigo são puníveis quando o responsável legal pela prestação do serviço, oficialmente notificado, deixa de desabilitar o acesso ao conteúdo ilícito de que trata o caput deste artigo. Art. 241-B. Adquirir, possuir ou armazenar, por qualquer meio, fotografia, vídeo ou outra forma de registro que contenha cena de sexo explícito ou pornográfica envolvendo criança ou adolescente: Pena - reclusão, de 1 (um) a 4 (quatro) anos, e 
ABREU, Jacqueline de Souza. Conceitos de valor, interpretação, direito e política: críticas de Bernard Williams a Ronald Dworkin. Revista Eletrônica Direito e Política, Programa de Pós-Graduação Stricto Sensu em Ciência Jurídica da UNIVALI, Itajaí, v.13, n.2, $2^{\circ}$ quadrimestre de 2018. Disponível em: www.univali.br/direitoepolitica - ISSN 1980-7791

Posteriormente, em abril de 2014, foi editada a Lei 12.965 (regulamentada pelo decreto 8.771/16), popularmente conhecida como Marco Civil da internet, uma espécie de constituição da internet ${ }^{28}$ que rege o uso da rede no Brasil, definindo direitos e deveres de usuários e provedores.

\section{A lei do o Marco Civil da internet criou diretrizes para garantir a proteção à} privacidade dos usuários, liberdade de expressão e retirada de conteúdo de sites, assegurou a neutralidade da rede e também previu o debate público sobre sua regulamentação. Em suma, surgiu para uma regularização das ações tomadas na internet estipulando direitos e deveres tanto para quem a utiliza, quanto para quem a distribui, regulamentando algumas sanções e termos, visando uma maior distribuição de privacidade, segurança e acessibilidade, considerando a liberdade

multa. $\S 1^{\circ} \mathrm{A}$ pena é diminuída de 1 (um) a $2 / 3$ (dois terços) se de pequena quantidade o material a que se refere o caput deste artigo. § $2^{\circ}$ Não há crime se a posse ou o armazenamento tem a finalidade de comunicar às autoridades competentes a ocorrência das condutas descritas nos arts. 240, 241, 241-A e 241-C desta Lei, quando a comunicação for feita por: I - agente público no exercício de suas funções; II - membro de entidade, legalmente constituída, que inclua, entre suas finalidades institucionais, o recebimento, o processamento e o encaminhamento de notícia dos crimes referidos neste parágrafo; III - representante legal e funcionários responsáveis de provedor de acesso ou serviço prestado por meio de rede de computadores, até o recebimento do material relativo à notícia feita à autoridade policial, ao Ministério Público ou ao Poder Judiciário. $\S 3^{\circ}$ As pessoas referidas no $\S 2^{\circ}$ deste artigo deverão manter sob sigilo o material ilícito referido. Art. 241-C. Simular a participação de criança ou adolescente em cena de sexo explícito ou pornográfica por meio de adulteração, montagem ou modificação de fotografia, vídeo ou qualquer outra forma de representação visual: Pena - reclusão, de 1 (um) a 3 (três) anos, e multa. Parágrafo único. Incorre nas mesmas penas quem vende, expõe à venda, disponibiliza, distribui, publica ou divulga por qualquer meio, adquire, possui ou armazena o material produzido na forma do caput deste artigo. Art. 241-D. Aliciar, assediar, instigar ou constranger, por qualquer meio de comunicação, criança, com o fim de com ela praticar ato libidinoso: Pena - reclusão, de 1 (um) a 3 (três) anos, e multa. Parágrafo único. Nas mesmas penas incorre quem: I - facilita ou induz o acesso à criança de material contendo cena de sexo explícito ou pornográfica com o fim de com ela praticar ato libidinoso; II - pratica as condutas descritas no caput deste artigo com o fim de induzir criança a se exibir de forma pornográfica ou sexualmente explícita. Art. 241-E. Para efeito dos crimes previstos nesta Lei, a expressão "cena de sexo explícito ou pornográfica" compreende qualquer situação que envolva criança ou adolescente em atividades sexuais explícitas, reais ou simuladas, ou exibição dos órgãos genitais de uma criança ou adolescente para fins primordialmente sexuais."

28 A expressão é oriunda da literatura de autores, como Marcelo Thompson ("[...] pode-se dizer que o Marco Civil é uma carta fundamental, uma Constituição, mesmo, para a internet brasileira. THOMPSON, Marcelo. Marco civil ou demarcação de direitos? Democracia, razoabilidade e as fendas na internet do Brasil. Revista de Direito Administrativo, Rio de Janeiro, v. 261, p. 203251, set./dez. $2012 . \quad$ Disponível em: <http://bibliotecadigital.fgv.br/ojs/index.php/rda/article/view/8856/7678>. Acesso em: 25 set 2017) e Arthur Coelho Bezerra e Igor Waltz ("[...] o Brasil aprovou em abril de 2014 o Marco Civil da Internet, a constituição do país para o setor, que estabelece direitos, deveres e garantias dos usuários.". (BEZERRA, Arthur Coelho; WALTZ, Igor. Privacidade, neutralidade e inimputabilidade da internet no brasil: avanços e deficiências no projeto do marco civil. Revista Eptic Online, v. 16, n. 2, p.157-171, maio/ago. 2014. Disponível em: <https://seer.ufs.br/index.php/eptic/article/viewFile/2276/1954 >. Acesso em: 25 set 2017). 
ABREU, Jacqueline de Souza. Conceitos de valor, interpretação, direito e política: críticas de Bernard Williams a Ronald Dworkin. Revista Eletrônica Direito e Política, Programa de Pós-Graduação Stricto Sensu em Ciência Jurídica da UNIVALI, Itajaí, v.13, n.2, $2^{\circ}$ quadrimestre de 2018. Disponível em: www.univali.br/direitoepolitica - ISSN 1980-7791

de expressão para responsabilização de provedores por conteúdos de terceiros em seu art. 19, que versa a respeito da responsabilidade civil dos provedores de aplicações de internet e inicia a disciplina do tema indicando que o regime adotado no país tem por intuito preservar a liberdade de expressão e evitar a censura na rede.

A exceção à regra se dá para conteúdo que viole a intimidade de terceiro ou contenha cenas de nudez ou de atos sexuais de caráter privado, divulgadas sem a sua autorização. Nesse caso, a plataforma será responsabilizada subsidiariamente se, notificada pelo participante das imagens ou por seu representante legal, não retirar o conteúdo publicado, ou seja, não há necessidade de uma decisão judicial afirmando o caráter ilícito do conteúdo, conforme preceitua o art. 21 da Lei.

A responsabilização dos provedores no Marco Civil se dá pela responsabilidade subjetiva, ou seja, ele afasta a responsabilidade de natureza objetiva, pela simples exibição do conteúdo danoso, seja com base na teoria do risco, seja com base no defeito do serviço prestado. Consoante a esta determinação, Carlos Affonso Souza e Ronaldo Lemos firmam o entendimento que a legislação do Marco Civil determina a salvaguarda dos provedores de aplicações, eis que os mesmos somente serão responsabilizados se não cumprirem ordem judicial para a retirada do material ofensivo. ${ }^{29}$

Ao garantir um espaço central para o tema da responsabilidade civil, delimitando o regime de responsabilização de provedores, o Marco Civil fortalece a tutela da liberdade de expressão e garante que novos modelos de negócio possam prosperar. O estímulo às liberdades e ao potencial de inovação da Internet não é usualmente lembrado quando se debate temas envolvendo responsabilidade civil. ${ }^{30}$

\footnotetext{
29 SOUZA, Carlos Affonso e LEMOS, Ronaldo. Marco civil da internet: construção e aplicação. Juiz de Fora: Editar Editora Associada Ltda., 2016, p. 101.

30 SOUZA, Carlos Affonso e LEMOS, Ronaldo. Marco civil da internet: construção e aplicação. Juiz de Fora: Editar Editora Associada Ltda., 2016, p. 108.
} 
ABREU, Jacqueline de Souza. Conceitos de valor, interpretação, direito e política: críticas de Bernard Williams a Ronald Dworkin. Revista Eletrônica Direito e Política, Programa de Pós-Graduação Stricto Sensu em Ciência Jurídica da UNIVALI, Itajaí, v.13, n.2, $2^{\circ}$ quadrimestre de 2018. Disponível em: www.univali.br/direitoepolitica - ISSN 1980-7791

A liberdade de expressão do pensamento, considerada como um direito que qualquer pessoa tem de exteriorizar, sob qualquer forma, o que pensa, ${ }^{31}$ pode ser vista sob diversas perspectivas. Reconhecida como princípio fundamental do Estado Democrático de Direito brasileiro, pode ser analisada sob a ótica da difusão de valores culturais, ${ }^{32}$ na medida em que expressa o direito à livre manifestação e propagação de ideias.

Sob uma ótica democrática, pode ser compreendida como uma ferramenta para o exercício de outros direitos e, até mesmo como uma pré-condição para a democracia. ${ }^{33}$ Sob a perspectiva democrática, a liberdade de expressão consiste numa liberdade positiva, um direito fundamental que exige uma ação positiva do Estado, quando indispensável para promover a livre comunicação, pressupondo, portanto, ações positivas do Estado, consistentes "em prestações normativas (aprovação de leis sobre o direito de informar) ou prestações materiais (meios ou instrumentos para o exercício da liberdade de informar)".34 Ou seja, esta perspectiva impõe aos poderes públicos "não apenas o dever de absterem-se de violar esses direitos, mas também a obrigação de promovê-los concretamente, e de garanti-los diante de ameaças decorrentes da ação de particulares e de grupos privados". 35

O Supremo Tribunal Federal, no ano de 2009, aproximou-se da jurisprudência desenvolvida pela Suprema Corte americana no julgamento da ADPF 130, consagrando o entendimento de que na hipótese de colisão de princípios constitucionais a liberdade de expressão possui um caráter de preferência sobre os direitos de personalidade: "quando se tem um conflito possível entre a liberdade

\footnotetext{
${ }^{31}$ SILVA, José Afonso da. Curso de direito constitucional positivo. 33 ed. São Paulo: Malheiros, 2015.

32 FARIAS, Edilsom. Liberdade de expressão e comunicação: teoria e proteção constitucional. São Paulo: Revista dos Tribunais, 2004.

33 SUNSTEIN, Cass. R. Democracy and the problem of free speech. New York: The Free Press, 1995.

34 FARIAS, Edilsom. Liberdade de expressão e comunicação: teoria e proteção constitucional. São Paulo: Revista dos Tribunais, 2004, p. 78.

35 SARMENTO, Daniel. Liberdade de expressão, pluralismo e o papel promocional do Estado. Revista Diálogo Jurídico, Salvador, n. 16, 2007.
} 
ABREU, Jacqueline de Souza. Conceitos de valor, interpretação, direito e política: críticas de Bernard Williams a Ronald Dworkin. Revista Eletrônica Direito e Política, Programa de Pós-Graduação Stricto Sensu em Ciência Jurídica da UNIVALI, Itajaí, v.13, n.2, $2^{\circ}$ quadrimestre de 2018. Disponível em: www.univali.br/direitoepolitica - ISSN 1980-7791

e sua restrição deve-se defender a liberdade. O preço do silêncio para a saúde institucional dos povos é muito mais alto do que o preço da livre circulação das ideias". ${ }^{36}$

Segundo Daniel Sarmento, importante, portanto, sejam determinados parâmetros que permitam a consideração de um discurso como sendo de ódio, sob pena de minar a abertura e a pluralidade exigidas pelo regime democrático e que orientam a formatação jurídica da sociedade brasileira. ${ }^{37}$ Reverbera-se a ideia que urge a imposição de limites à liberdade de expressão no meio digital, como forma de "proteção dos cidadãos contra violações de seus direitos fundamentais causadas por essa liberdade, principalmente contra as violações levadas a cabo pelos veículos de comunicação de massa", ${ }^{38}$ e em casos como o de cyberbullying, por exemplo.

A questão da virtualização da informação e a potencialidade lesiva é o que mais atormenta as vítimas do cyberbullying, pois a questão da incontrolabilidade das condutas aliada à questão do anonimato da prática resume-se em riscos globais:

Ontem, cada um de nós administrava o risco de dano em sua vida pessoal. Hoje, os riscos apontam a possibilidade de riscos globais, não delimitáveis quanto às suas vítimas. Por um lado, porque um dano ao sistema afeta todos. Por outro, porque há novos instrumentais de produção de dano, intencionais ou não, que adquirem imensurável ou incontrolável repercussão, visto a sua diferenciada potencialidade técnica em produzir lesividades (internet, meios de comunicação, etc). ${ }^{39}$

\footnotetext{
${ }^{36}$ Supremo julga Lei de Imprensa incompatível com a Constituição Federal. Disponível em: $<$ http://www.stf.jus.br/portal/cms/vernoticiadetalhe.asp?idconteudo=107402>. Acesso em 04 jul 2018.
}

37 SARMENTO, Daniel. Livres e iguais. Estudos de Direito Constitucional. Rio de Janeiro: Lumen Juris, 2006.

38 FARIAS, Edilsom. Liberdade de expressão e comunicação: teoria e proteção constitucional. São Paulo: Revista dos Tribunais, 2004, p. 18.

39 LAMY, Marcelo. Conflitos dogmáticos da proteção penal do ambiente e da ordem econômica. In Revista Brasileira de Direito Constitucional - RBDC n. 11 - Jan/Jun 2008, p. 03. Disponível em: <http://www.esdc.com.br/RBDC/RBDC-11/RBDC-11-013-Marcelo_Lamy.pdf>. Acesso em 09 ago. 2018. 
ABREU, Jacqueline de Souza. Conceitos de valor, interpretação, direito e política: críticas de Bernard Williams a Ronald Dworkin. Revista Eletrônica Direito e Política, Programa de Pós-Graduação Stricto Sensu em Ciência Jurídica da UNIVALI, Itajaí, v.13, n.2, $2^{\circ}$ quadrimestre de 2018. Disponível em: www.univali.br/direitoepolitica - ISSN 1980-7791

No Brasil, de acordo com o Código Penal, o cyberbullying já está tipificado como um crime contra a honra praticado em meio virtual, podendo ser enquadrado em: calúnia, injúria ou difamação, havendo previsão de aumento de pena quando o crime for praticado na presença de mais pessoas, por meio que facilite a divulgação, como a internet. O cyberstalking (ciberperseguição), por sua vez, seria o crime de ameaça, igualmente tipificado no Código Penal, podendo ser uma contravenção penal - a perturbação da tranquilidade, dependendo da interpretação, prevista na Lei das Contravenções Penais (Decreto-lei 3.688/41). Entretanto, no caso de crimes praticados por menores de idade, a prática será caracterizada como ato infracional, punível com medidas socioeducativas previstas no Estatuto da Criança e do Adolescente (ECA - Lei 8.069/90).

As crianças e os adolescentes que praticam essas contravenções também devem ser inseridas em programa escolar de combate ao bullying. Em 2015, a Lei 13.185, instituiu o Programa de Combate à Intimidação Sistemática. O texto propôs a substituição do termo bullying por "intimidação sistemática", a fim de fugir do estrangeirismo, com a finalidade precípua de prevenir e combater a prática da intimidação sistemática em toda a sociedade, a considerando em seu $\S 1^{0}$ do art. $10,[\ldots]$ todo ato de violência física ou psicológica, intencional e repetitivo que ocorre sem motivação evidente, praticado por indivíduo ou grupo, contra uma ou mais pessoas, com o objetivo de intimidá-la ou agredi-la, causando dor e angústia à vítima, em uma relação de desequilíbrio de poder entre as partes envolvidas.

Nessa perspectiva, recente decisão da 34a Câmara de Direito Privado do TJSP condenou a administradora de um grupo de WhatsApp a pagar indenização por danos morais a um garoto que sofreu cyberbullying no grupo. ${ }^{40}$

Autores vítimas de ofensas graves via WhatsApp. Prova incontroversa do ocorrido, por meio de ata notarial. Ré que, na qualidade de criadora do grupo, no qual ocorreram as ofensas, poderia ter removido os autores das ofensas, mas

\footnotetext{
40 Em resumo, a ré tinha 15 anos quando criou um grupo no aplicativo com o nome "jogo na casa da Gigi", com a finalidade de convidar os colegas da escola para assistirem aos jogos da Copa de 2014 em sua casa. Passado o evento, o grupo continuou ativo e membros começaram a ofender a sexualidade da vítima. Dona de grupo de WhatsApp é condenada por permitir bullying. Disponível em: <https://www1.folha.uol.com.br/cotidiano/2018/07/dona-de-grupo-de-whatsapp-econdenada-por-permitir-bullying.shtml>. Acesso em 09 ago. 2018.
} 
ABREU, Jacqueline de Souza. Conceitos de valor, interpretação, direito e política: críticas de Bernard Williams a Ronald Dworkin. Revista Eletrônica Direito e Política, Programa de Pós-Graduação Stricto Sensu em Ciência Jurídica da UNIVALI, Itajaí, v.13, n.2, 20 quadrimestre de 2018. Disponível em: www.univali.br/direitoepolitica - ISSN 1980-7791

não o fez, mostrando ainda ter-se divertido com a situação por meio de emojis de sorrisos com os fatos. Situação narrada como bullying, mas que se resolve simplesmente pelo artigo 186 do Código Civil. Danos morais fixados em valor moderado, no total de $\mathrm{R} \$ 3.000,00$ ( $\mathrm{R} \$ 1.000,00$ por autor), porque a ré tinha apenas 15 anos por ocasião dos fatos, servindo então a pena como advertência para o futuro e não como punição severa e desproporcional. Apelo provido. ${ }^{41}$

A responsabilização neste caso se deu em razão da culpa in vigilando da ré, fato que foi ressaltado na fundamentação da decisão "[...] o criador do grupo é sempre denominado seu administrador por uma razão simples: pode adicionar e remover termos utilizados na rede quem bem quiser e à hora em que quiser. Ou seja, no caso dos autos, quando as ofensas, que são incontroversas, provadas via notarial, e são graves, começaram, a ré poderia simplesmente ter removido quem ofendia e/ou ter encerrado o grupo $[\ldots]^{\prime \prime 2}$.

Neste mesmo sentido a $6^{a}$ Câmara Cível do Tribunal de Justiça do Rio Grande do Sul condenou uma mãe a pagar indenização por danos morais perpetrados por seu filho. O caso compreendia-se no site criado pelo filho da ré com a finalidade de ofender um colega de classe, através de fotos e mensagens ofensivas ${ }^{43}$. Considerou a decisão, que restou "[...] incontroversa a ilicitude praticada pelo descendente da demandada ante a prática de bullying (termo comumente utilizado em ações trabalhistas para definir assédio moral e ameaças psicológicas aos trabalhadores)."44

\footnotetext{
41 TJSP. APELAÇÃO No 1004604-31.2016.8.26.0291. Disponível em: <https://www.conjur.com.br/dl/administrador-grupo-whatsapp-condenado.pdf>. Acesso em 09 ago. 2018.

42 TJSP. APELAÇÃO No 1004604-31.2016.8.26.0291. Disponível em: <https://www.conjur.com.br/dl/administrador-grupo-whatsapp-condenado.pdf>. Acesso em 09 ago. 2018.
}

43 Mãe é condenada a pagar indenização por cyberbullying cometido pelo filho no Rio Grande do Sul. Disponível em: <https://oglobo.globo.com/brasil/mae-condenada-pagarindenizacao-por-cyberbullying-cometido-pelo-filho-no-rio-grande-do-sul-2984952>. Acesso em 09 ago. 2018.

\footnotetext{
44 TJRS. APELAÇÃO No $\mathbf{7 0 0 3 1 7 5 0 0 9 4 . ~ D i s p o n i ́ v e l ~ e m : ~}$ <http://www1.tjrs.jus.br/site_php/consulta/consulta_processo.php?nome_comarca=Tribunal+de+ Justi\%E7a\&versao=\&versao_fonetica $=1 \&$ tipo $=1 \&$ id_comarca $=700 \&$ num_processo_mask $=7003175$ 0094\&num_processo $=70031750094 \&$ codEmenta $=3620419 \&$ temIntTeor $=$ true $>$. Acesso em 09 ago. 2018.
} 
ABREU, Jacqueline de Souza. Conceitos de valor, interpretação, direito e política: críticas de Bernard Williams a Ronald Dworkin. Revista Eletrônica Direito e Política, Programa de Pós-Graduação Stricto Sensu em Ciência Jurídica da UNIVALI, Itajaí, v.13, n.2, $2^{\circ}$ quadrimestre de 2018. Disponível em: www.univali.br/direitoepolitica - ISSN 1980-7791

Como se percebe, resta evidente que a informatização está estruturando um novo tipo de sociedade, onde a moeda de troca é a informação, assim, considerando que o ritmo em que a informática evolui é exponencialmente superior ao ritmo em que evolui a atividade legislativa, esta não bastará para solucionar casos concretos.

De fato, é preciso criar regras claras e modernas, de alta carga principiológica, aptas a acompanhar a mudança tecnológica. Sendo a lei sempre dependente da realidade social que busca ordenar e a ela funcionalmente se vincula, objetivando emprestar-Ihe segurança através da predeterminação de modelos, ${ }^{45}$ de se inferir que nem sempre o legislador conseguirá abarcar todos os acontecimentos futuros, especialmente em uma sociedade contemporânea e multicultural como a nossa, tal perspectiva acarretará lacunas legislativas a serem preenchidas pelo judiciário. Também é preciso conciliar essas regras com a nova geração de internautas e adequar a punibilidade ao perfil dos agentes.

Não é uma tarefa fácil criar mecanismos para regularizar esta realidade, pois como bem advertem Jose Luis Bolzan de Morais e Elias Jacob Neto, o recurso às legislações nacionais é insuficiente para garantir a proteção dos direitos fundamentais violados: "em que pese essa limitação da discussão no âmbito do Estado-nação, não se pode desconsiderar a importância, ainda que simbólica, dessas legislações". ${ }^{46}$

[...] temos que questionar se uma ferramenta tão "sólida" quanto a lei é capaz de controlar algo tão "líquido". O Marco Civil possui enorme importância para o País, sendo sua aprovação, definitivamente, um ganho para a sociedade brasileira e, em muitos pontos, um exemplo a ser seguido por outros países. No entanto, é preciso reconhecer que o mundo,

\footnotetext{
45 CALMON DE PASSOS, José Joaquim. Direito, poder, justiça e processo: julgando os que nos julgam. Rio de Janeiro: Forense, 2000. p. 93.

46 BOLZAN DE MORAIS Jose Luis; NETO, Elias Jacob de Menezes. Quem é anônimo no mundo dos metadados? $O$ problema do anteprojeto de lei para proteção de dados pessoais. Disponível em: <http://emporiododireito.com.br/tag/o-problema-do-anteprojeto-de-leipara-protecao-de-dados-pessoais/\#_ftn4>. Acesso em 22 set 2017.
} 
ABREU, Jacqueline de Souza. Conceitos de valor, interpretação, direito e política: críticas de Bernard Williams a Ronald Dworkin. Revista Eletrônica Direito e Política, Programa de Pós-Graduação Stricto Sensu em Ciência Jurídica da UNIVALI, Itajaí, v.13, n.2, $2^{\circ}$ quadrimestre de 2018. Disponível em: www.univali.br/direitoepolitica - ISSN 1980-7791

assim como a vida, é - cada vez mais - complexo e caótico para caber no espaço "rígido e seguro" da lei. ${ }^{47}$

Considerada uma forma de desenvolvimento da personalidade, a liberdade de expressão pode ser vista, também, em sua dimensão coletiva quando diante de um meio de comunicação social ou de massa ${ }^{48}$ como a internet. O Marco Civil preocupou-se em garantir que não haja nenhum tipo de censura na internet, deixando clara a liberdade de expressão na rede já no caput do art. 20 , tornando a liberdade de expressão um princípio norteador do uso da rede: a liberdade de expressão, considerada como liberdade de externar ideias, juízos de valor e as mais variadas manifestações do pensamento, além de já ser amplamente protegida pelo constituinte, apresenta no MCI tutela destacada, sendo considerada um fundamento e um princípio para a disciplina do uso da internet no Brasil e condição para o pleno exercício do direito de acesso. ${ }^{49}$

Conforme ressaltam Salete Oro Boff e Vinícius Borges Fortes, é necessário promover uma imersão conceitual do Direito no ciberespaço, visando preservar os direitos humanos fundamentais à privacidade. ${ }^{50}$ Extrai-se que a livre manifestação da expressão assumiu papel de destaque no Direito Digital brasileiro, o que eleva a necessidade de discussão sobre liberdade de expressão, agora não somente expressada, mas também, publicada, quando confrontada com os demais direitos fundamentais, a fim de salvaguardar o equilíbrio normativo e a harmonia social.

\footnotetext{
47 BOLZAN DE MORAIS Jose Luis; NETO, Elias Jacob de Menezes. A "liquidez" da surveillance cabe nos limites da "solidez" do marco civil da Internet? Disponível em: <http://emporiododireito.com.br/a-liquidez-da-surveillance-cabe-nos-limites-da-solidez-do-marcocivil-da-internet-por-jose-luis-bolzan-de-morais-e-elias-jacob-de-menezes-neto/>. Acesso em 22 set. 2017.

48 BARROSO, Luis Roberto. Colisão entre Liberdade de Expressão e Direitos da Personalidade. Critérios de Ponderação: interpretação Constitucionalmente Adequada do Código Civil e da Lei de Imprensa. Revista de Direito Administrativo, Rio de Janeiro, v. 235, p. 19, jan. 2004. Disponível em: <http://bibliotecadigital.fgv.br/ojs/index.php/rda/article/view/45123/45026>. Acesso em: 10 out. 2017.
}

49 TEFFÉ, Chiara Spadaccini de; MORAES, Maria Celina Bodin de. Redes sociais virtuais: privacidade e responsabilidade civil. Análise a partir do Marco Civil da Internet. Revista Pensar, Fortaleza, v. 22, n. 1, p. 113, jan./abr. 2017.

50 BOFF, Salete; FORTES, Vinícius Borges. A Privacidade e a Proteção dos Dados Pessoais no Ciberespaço como um Direito Fundamental: perspectivas de construção de um marco regulatório para o Brasil. Seqüência (Florianópolis), n. 68, p. 109-127, jun. 2014, p. 124. 
ABREU, Jacqueline de Souza. Conceitos de valor, interpretação, direito e política: críticas de Bernard Williams a Ronald Dworkin. Revista Eletrônica Direito e Política, Programa de Pós-Graduação Stricto Sensu em Ciência Jurídica da UNIVALI, Itajaí, v.13, n.2, $2^{\circ}$ quadrimestre de 2018. Disponível em: www.univali.br/direitoepolitica - ISSN 1980-7791

\section{A INTERNET E A POSITIVAÇÃo DAS CONDUTAS NO DIREITO NORTE- AMERICANO}

Ao contrário do Brasil, nos Estados Unidos o anonimato é considerado um direito decorrente da liberdade de expressão e por mais que essa perspectiva possa soar estranha ao sistema brasileiro que, nesse particular, adotou postura diametralmente oposta, os posicionamentos assumidos pela Suprema Corte norteamericana igualmente revelam uma defesa ampla da liberdade de expressão em detrimento de outros direitos. ${ }^{51}$

Considerando a vasta experiência norte-americana na elaboração de procedimentos destinados a garantir a proteção da liberdade de expressão dos usuários de internet e a possibilidade de responsabilização dos autores de ilícitos, Matthew Ruedy, em artigo publicado em 2008 para o North Carolina Journal of Law \& Technology, discutiu as repercussões legais do caso que viria mais tarde a trazer o primeiro veredito sobre cyberbullying da história do direito norteamericano: ${ }^{52}$ o caso Megan Meier.

No ano de 2006, Lori Drew, de 49 anos, juntamente com sua filha Sarah, de 13 anos e uma empregada da família, Ashley Grills, criaram um perfil falso no site MySpace.com. Neste perfil elas inventaram a identidade de Josh Evans, um garoto de 16 anos, para se comunicar com uma garota rival de Sarah, da mesma idade. Dentre outras interações, em uma tarde de outubro de 2006 o perfil falso enviou uma mensagem escrita: "the world would be a better place without you", em tradução livre: o mundo seria um lugar melhor sem você. Em audiência, Ashley revelou que esta mensagem teve como resposta quase imediata: "you're the kind of boy a girl would kill herself over", em tradução livre: você é o tipo de garoto

51 SARMENTO, Daniel. Livres e iguais. Estudos de Direito Constitucional. Rio de Janeiro: Lumen Juris, 2006.

52 Verdict in MySpace Suicide Case. Disponível em: https://www.nytimes.com/2008/11/27/us/27myspace.html. Acesso em 25 jul. 2018. 
ABREU, Jacqueline de Souza. Conceitos de valor, interpretação, direito e política: críticas de Bernard Williams a Ronald Dworkin. Revista Eletrônica Direito e Política, Programa de Pós-Graduação Stricto Sensu em Ciência Jurídica da UNIVALI, Itajaí, v.13, n.2, $2^{\circ}$ quadrimestre de 2018. Disponível em: www.univali.br/direitoepolitica - ISSN 1980-7791

pelo qual uma garota se mataria. Na mesma tarde, Megan Meier, de 13 anos, foi encontrada enforcada em seu quarto, morrendo no dia seguinte. ${ }^{53}$

O caso chamou a atenção por ser o primeiro relacionado ao "cyberbullying", termo usado para definir a perseguição e a humilhação de uma pessoa através de e-mails e sites de relacionamento. No Estado do Missouri, os promotores não conseguiram encontrar leis que justificassem um processo judicial contra Drew. Mas autoridades em Los Angeles, na Califórnia, onde o MySpace está baseado, decidiram processála por crimes normalmente cometidos por hackers. O júri a inocentou das acusações mais graves, como a de ter a intenção de causar stress emocional. Mas ela foi considerada culpada de três acusações sobre uso indevido de computadores, inclusive de ter acessado um aparelho sem autorização. ${ }^{54}$

Na época, o caso Megan Meier impulsionou a criação de diversas respostas legislativas de cunho estadual nos Estados Unidos: a nação reagiu fortemente ao suicídio de Megan, demandando que Lori Drew fosse denunciada por suas ações. O Governo Federal e muitos estados não reconhecem o cyberbullying como um crime à parte. Apesar de que leis federais que protegem pessoas de "assédio" através das fronteiras interestaduais existam, promotores são forçados a tentar encaixar o comportamento de cyberbullying dentro dos existentes estatutos do "assédio" e da "perseguição". O encaixe realizado é "tênue" para dizer o mínimo. Uma síntese das comunicações correntes e leis de crimes computacionais ajuda bastante a determinar os limites de qualquer lei anti-cyberbullying. ${ }^{55}$

Portanto, ao pesquisar, Ruedy atestou a grande dificuldade em encontrar o cyberbullying tipificado em legislações americanas. Dentre as legislações então vigentes, o tipo "ameaça interestadual", apesar de na época já ser usado para casos de cyberstalking (ciberperseguição), não se adequava com a prática do

53 Parents: Cyber Bullying Led to Teen's Suicide. Disponível em: https://abcnews.go.com/GMA/story?id=3882520\&page=1. Acesso em: 20 jul. 2018.

54 Americana é condenada por trote na internet que provocou suicídio. Disponível em: https://www.bbc.com/portuguese/reporterbbc/story/2008/11/081127_internetabusoml.shtml. Acesso em: 10 mar. 2018.

55 RUEDY, Matthew. Repercussions of a MySpace Teen Suicide: Should Anti-Cyberbullying Laws Be Created: North Carolina Journal of Law: 2008, p. 331. 
ABREU, Jacqueline de Souza. Conceitos de valor, interpretação, direito e política: críticas de Bernard Williams a Ronald Dworkin. Revista Eletrônica Direito e Política, Programa de Pós-Graduação Stricto Sensu em Ciência Jurídica da UNIVALI, Itajaí, v.13, n.2, $2^{\circ}$ quadrimestre de 2018. Disponível em: www.univali.br/direitoepolitica - ISSN 1980-7791

cyberbullying, e, em um caso como o de Megan, não houve ameaça nem tentativa de sequestro envolvidas, o que destoa do conteúdo do diploma legal; 56 estatutos federais como o 47 U.S.C. §223, que dispõe sobre chamadas telefônicas interestaduais obscenas e assediosas e o $\S 223(\mathrm{a})$ (1) (C), que proíbe chamadas telefônicas interestaduais anônimas que ameacem, assediem, abusem ou incomodem a quem recebe a chamada, não cobriam o meio virtual de comunicação, apenas o telefone, sendo ponto central do argumento do autor americano, que na época pedia por uma solução fundamentada em analogia, já que, segundo ele, as atitudes de alguém do título §223(a) (1) (C) na internet seria cyberbullying. 57

Atualmente, dos 51 estados americanos, 49 estados têm políticas escolares (19 com monitoramento fora de campus) sobre cyberbullying, 48 estados possuem legislação estadual que incluem cyberbullying ou assédio on line, 45 possuem sanções escolares para cyberbullying e 44 possuem sanções penais para cyberbullying e assédio eletrônico, ${ }^{58}$ inclusive Washington D.C. se uniu aos demais, tendo em junho de $2012,{ }^{59}$ publicado sua manifestação legal contra a prática.

Porém, quando a matéria é estudada sob as lentes do poder federal americano a resposta não se trata de inércia, e sim de confrontamento, conflito esse, gerado pela Primeira Emenda da Constituição Americana, a qual diz que: "O Congresso não legislará no sentido de estabelecer uma religião, ou proibindo o livre exercício dos cultos; ou cerceando a liberdade de palavra, ou de imprensa, ou o direito do povo de se reunir pacificamente, e de dirigir ao Governo petições para a reparação

5618 U.S.C. $\S 875(c)$ : Quem quer que transmita entre estados ou no comércio internacional qualquer comunicação que contenha ameaça de sequestro de qualquer pessoa ou ameace de lesão entre usuários, deve ser multada sob este título ou detida não mais do que cinco anos ou ambos. Disponível em: https://www.law.cornell.edu/uscode/text/18/875. Acesso em: 23 jul. 2018.

57 RUEDY, Matthew. Repercussions of a MySpace Teen Suicide: Should Anti-Cyberbullying Laws Be Created. North Carolina Journal of Law: 2008, p. 333.

58 Bullying Laws Across America. Disponível em: <https://cyberbullying.org/bullying-laws>. Acesso em: 25 jul. 2018.

59 Office of the State Superintendent of Education (Osse) Bullying Policy. Disponível em: <https://osse.dc.gov/sites/default/files/dc/sites/osse/publication/attachments/OSSE\%20Bullying\% 20Policy.pdf>. Acesso em: 25 jul. 2018. 
ABREU, Jacqueline de Souza. Conceitos de valor, interpretação, direito e política: críticas de Bernard Williams a Ronald Dworkin. Revista Eletrônica Direito e Política, Programa de Pós-Graduação Stricto Sensu em Ciência Jurídica da UNIVALI, Itajaí, v.13, n.2, $2^{\circ}$ quadrimestre de 2018. Disponível em: www.univali.br/direitoepolitica - ISSN 1980-7791

de seus agravos." 60 Esse parágrafo é a fonte do direito de liberdade de expressão, de imprensa e de religião americanos, e todo problema do reconhecimento da prática criminosa do cyberbullying em âmbito federal americano, se resume em um confronto direto com seu conteúdo.

Apesar disso, interpretações legais deste texto de grande flexibilidade e amplitude hermenêutica, estão homogeneamente espalhadas pela jurisprudência legal americana. Um dos desdobramentos é a discussão da liberdade de expressão em escolas. Sobre isto, interessante a coletânea de quatro decisões da Suprema Corte americana sobre liberdade de expressão em escolas públicas realizada por Martha McCarthy, ${ }^{61}$ onde aponta que estas decisões já foram discutidas exaustivamente pela literatura legal americana se tornando base jurisprudencial para o assunto.

Tinker v. Des Moines Independent Community School District ${ }^{62}$ entendeu que estudantes possuem direito à liberdade de expressar seus pontos de vista ideológicos em escolas públicas, a menos que autoridades escolares prevejam substancial disrupção por causa da expressão, ou se colidir com o direito de outros. Bethel School District No. 403 v. Fraser ${ }^{63}$ apontou que expressão estudantil baixa, vulgar e ofensiva em escolas públicas não é protegida pela Primeira Emenda, embora tal expressão possa ser protegida para adultos fora dos domínios da escola. Hazelwood School District $v$. Kuhlmeier ${ }^{64}$ sobre a possibilidade de limitar a expressão de aluno que fale em nome da escola e Morse $v$. Frederick ${ }^{65}$ trouxe que

60 A Constituição dos Estados Unidos da América. Disponível em: http://www.uel.br/pessoal/jneto/gradua/historia/recdida/ConstituicaoEUARecDidaPESSOALJNETO.p df. Acesso em: 30 jul. 2018.

61 MCCARTHY, Martha. Cyberbullying Laws And First Amendment Rulings: Can They Be Reconciled? Mississippi Law Journal: 2014.

62 Tinker v. Des Moines Independent Community School District. Disponível em: https://www.law.cornell.edu/supremecourt/text/393/503. Acesso em: 30 jul. 2018.

63 Bethel School District No. 403 v. Fraser. Disponível em: https://www.law.cornell.edu/supremecourt/text/478/675. Acesso em: 28 jul. 2018.

64 Hazelwood School District v. Kuhlmeier. Disponível em: http://www.uscourts.gov/educational-resources/educational-activities/facts-and-case-summaryhazelwood-v-kuhlmeier. Acesso em: 26 jul. 2018.

65 Morse v. Frederick. Disponível em: https://supreme.justia.com/cases/federal/us/551/393/. Acesso em: 28 jul. 2018. 
ABREU, Jacqueline de Souza. Conceitos de valor, interpretação, direito e política: críticas de Bernard Williams a Ronald Dworkin. Revista Eletrônica Direito e Política, Programa de Pós-Graduação Stricto Sensu em Ciência Jurídica da UNIVALI, Itajaí, v.13, n.2, $2^{\circ}$ quadrimestre de 2018. Disponível em: www.univali.br/direitoepolitica - ISSN 1980-7791

expressão estudantil promovendo drogas ilegais poderia ser reduzida sem necessidade da disrupção trazida no caso Tinker.

Estes são os modelos principais de jurisprudência sobre liberdade de expressão em escolas, e, segundo McCarthy, ainda em 2014: "nenhum destes casos analisados envolveu cyberbullying entre estudantes, e apesar do crescente volume de decisões de cortes inferiores, a Suprema Corte declinou consistentemente a revisão de recursos dos casos envolvendo a expressão eletrônica de estudantes. Consequentemente, há mais incerteza do que clareza". ${ }^{66}$

Ruedy baseou sua análise jurisprudencial do caso Megan Meier em dois precedentes os quais julgava serem relevantes para a análise do caso na época, argumentando em seu artigo que: "a análise de potenciais leis anti-cyberbullying serão conduzidas sob estas atuais doutrinas devido a tais medidas legislativas e há pouca chance de a Suprema Corte alterar a doutrina Watts v. United States ${ }^{67}$ antes que qualquer lei assim passe, porque toda lei anti-cyberbullying restringiria a liberdade de expressão, assim, potenciais leis anti-cyberbullying devem adequarse com as exceções à Primeira Emenda articuladas em Brandenburg v. Ohio."68 69

Importante destacar a frase de Watts $v$. United States: "o que é uma ameaça deve ser distinguido do que é discurso constitucionalmente protegido", disposta a reconhecer que a chamada "ameaça real", não era protegida pela Primeira Emenda da constituição. Igualmente, Brandenburg v. Ohio foi um importante precedente, para determinar se a expressão se qualificava como incitamento à violação de lei, determinando três características para o tipo "incitamento": "(1) apologia expressa da violação da lei; (2) a apologia deve remeter imediatamente à violação da lei; e

${ }^{66}$ MCCARTHY, Martha. Cyberbullying Laws And First Amendment Rulings: Can They Be Reconciled? Mississippi Law Journal: 2014. p. 815

67 Watts v. United States, 394 U.S. 705 (1969). Disponível em: https://supreme.justia.com/cases/federal/us/394/705/. Acesso em: 23 jul. 2018.

68 Brandenburg v. Ohio, 395 U.S. 444 (1969). Disponível em: https://www.law.cornell.edu/supremecourt/text/395/444. Acesso em: 30 jul. 2018.

69 RUEDY, Matthew. Repercussions of a MySpace Teen Suicide: Should Anti-Cyberbullying Laws Be Created. North Carolina Journal of Law: 2008. p. 336. 
ABREU, Jacqueline de Souza. Conceitos de valor, interpretação, direito e política: críticas de Bernard Williams a Ronald Dworkin. Revista Eletrônica Direito e Política, Programa de Pós-Graduação Stricto Sensu em Ciência Jurídica da UNIVALI, Itajaí, v.13, n.2, $2^{\circ}$ quadrimestre de 2018. Disponível em: www.univali.br/direitoepolitica - ISSN 1980-7791

(3) à imediata violação da lei deve ser possível de ocorrer"70 ou seja, pode-se distinguir a presença de três elementos distintos: a iminência e a probabilidade da ação e a intenção do agente.

Inadequações destas jurisprudências com o caso de Megan Meier, no caso específico de Brandenburg $v$. Ohio foi a exigência de iminência dos atos praticados com o incitamento, o que destoa do modo em que é consumida informação na internet, e no caso Watts $v$. United States o problema é a falta de critério para se definir "ameaça real", dissonância que se somou à mudança de contexto social que o avanço tecnológico trouxe. Tudo isso acabou se tornando obstáculo no conflito do ponto de vista jurídico americano sobre a matéria, engessando a interpretação do que está ou não protegido pela liberdade de expressão através de peculiaridades que não somam à discussão, apenas a dificultam.

Assim, o que se observa no cenário jurídico norte-americano é que há ponderação de bens e interesses, sendo que a liberdade de expressão contida na Primeira Emenda possui peso e posição de preferência em relação aos demais direitos constitucionais e embora a discussão sobre cyberbullying em solo americano já esteja presente em âmbito jurídico e acadêmico desde a primeira década deste século, o que se observa é que ainda não há o reconhecimento do cyberbullying como um crime único, sendo a conduta julgada sobre as vertentes de ameaça, assédio e perseguição.

Contudo, acontecimentos recentes, demonstram que os Estados Unidos estão alterando gradativamente a interpretação sobre responsabilização em casos de cyberbullying, comparado ao que aconteceu no caso Megan Meier. No ano de 2013, duas adolescentes, de 12 e 14 anos, foram presas no Estado da Flórida após a prática de cyberbullying levar ao suicídio de uma colega, mesmo que a acusação tenho sido por "perseguição agravada". ${ }^{71}$ No mesmo sentido, em decisão de junho

\footnotetext{
${ }^{70}$ RUEDY, Matthew. Repercussions of a MySpace Teen Suicide: Should Anti-Cyberbullying Laws Be Created. North Carolina Journal of Law: 2008, p. 336.

${ }^{71}$ Adolescentes são presas após ciberbullying levar a suicídio de colega. Disponível em: 
ABREU, Jacqueline de Souza. Conceitos de valor, interpretação, direito e política: críticas de Bernard Williams a Ronald Dworkin. Revista Eletrônica Direito e Política, Programa de Pós-Graduação Stricto Sensu em Ciência Jurídica da UNIVALI, Itajaí, v.13, n.2, $2^{\circ}$ quadrimestre de 2018. Disponível em: www.univali.br/direitoepolitica - ISSN 1980-7791

de 2018, uma escola americana foi processada pelo suicídio de uma aluna que sofria bullying enquanto estudante daquela escola: um ano depois da morte de Mallory Grossman, seus pais entraram com ação contra a escola, acusando-a de ignorar as queixas da menina e de não tomar uma atitude mais enérgica para evitar o bullying entre os alunos. ${ }^{72}$

Claramente evidencia-se a importância da discussão acerca da responsabilização dos agentes precursores do cyberbullying, bem como da repercussão de seus atos na sociedade atual, cada vez mais adepta às novas tecnologias, afetando o cotidiano das pessoas. Pérez Luño, acertadamente expõe que o aumento das tecnologias de informação e comunicação tem correlação direta aos setores jurídicos e políticos, fatos que levam à necessidade de abordar a repercussão dessas tecnologias no exercício dos Direitos Humanos, ${ }^{73}$ porque em sociedades contemporâneas, a legitimação do Direito e do sistema político deve passar por um processo reflexivo racional dialógico de aceitação pelos cidadãos, exigindo-se um grau de engajamento e interação forte entre representantes e representados. ${ }^{74}$

Indiscutível que a internet seja fonte de informações livres e descentralizadas, como nunca se teve na história do planeta, e é indiscutível, também, que o uso irresponsável dessa tecnologia seja objeto de preocupação da sociedade e dos governos. Embora a própria internet possua mecanismos de controle de conteúdo, essa proteção não é suficiente nos casos de ataques de cyberbullying, o que acentua a importância em se discutir as formas de responsabilizar os praticantes de cyberbullying, no Brasil e no mundo.

\section{CONSIDERAÇÕES FINAIS}

72 Escola nos EUA é processada por suicídio de aluna que sofria bullying. Disponível em: https://g1.globo.com/mundo/noticia/escola-nos-eua-e-processada-por-suicidio-de-aluna-que-sofria-bullying.ghtml. Acesso em: 15 jul. 2018.

73 "En los últimos años se ha ampliado decisivamente la incidencia de las TIC y las NT em amplios ectores de la experiencia jurídica y política. Ello invita a plantear también su repercusión en el alcance y ejercicio de los derechos humanos.". LUÑO, Antonio-Enrique Pérez. Teledemocracia, Ciberciudadania y Derechos Humanos. Revista Brasileira de Políticas Públicas, Brasília, v. 4, n. 2, p. $11,2014$.

74 HABERMAS, Jürgen. Direito e Democracia: entre facticidade e validade. Rio de Janeiro: Tempo Brasileiro, 2003, p. 448. 
ABREU, Jacqueline de Souza. Conceitos de valor, interpretação, direito e política: críticas de Bernard Williams a Ronald Dworkin. Revista Eletrônica Direito e Política, Programa de Pós-Graduação Stricto Sensu em Ciência Jurídica da UNIVALI, Itajaí, v.13, n.2, $2^{\circ}$ quadrimestre de 2018. Disponível em: www.univali.br/direitoepolitica - ISSN 1980-7791

Ao final, destaca-se o fato de que estamos apenas no início de uma era de significativas oportunidades para o poder das multidões conectadas em rede ${ }^{75} \mathrm{e}$ que a regulamentação da vida em sociedade enseja desafios importantes, primordialmente quando se fala de sociedades conectadas.

Tendo-se presente que a liberdade de expressão está diretamente ligada ao sistema democrático, o qual garante opinião livre, resguardada pelas constituições do Brasil e dos Estados Unidos, constituindo-se como direito fundamental de cada cidadão, igualmente, tem-se que tal direito não é absoluto.

É o que se visualizou no caso dos crimes cometidos em rede, que adquiriram nova roupagem com o uso de computadores e internet, especialmente quando se trata do crime cibernético denominado cyberbullying, ocasião em que entra em jogo a colisão de duas gamas de direitos fundamentais: de um lado, o direito à livre manifestação da expressão e, do outro, os direitos da personalidade.

Perante essa realidade se observou que há necessidade de sopesar os valores postos em jogo, eis que o cometimento do delito cibernético do cyberbullying deixa marcas indeléveis aos direitos da personalidade, honra, intimidade, imagem e de integridade física, eis que muitas vezes resultam em traumas profundos, e em alguns casos, à morte.

Assim, mais do que abordar a questão como um problema de saúde pública global, deve-se estar atento para os efeitos que o meio propicia a tais delitos em razão da rapidez da propagação da mensagem que em poucos minutos atinge uma plateia de proporções incomensuráveis. Por fim, se extrai que é uma situação complexa, especialmente pela volatilidade dos conteúdos no espaço da internet, o que se choca com a lentidão e vagarosidade dos sistemas legislativo e judiciário dos países, fazendo com que se tenha desafios complexos a serem enfrentados pela sociedade e pelos governos.

\footnotetext{
75 RODOTÀ, Stefano. A Vida na Sociedade da Vigilância: a privacidade hoje. Tradução: Danilo Doneda e Luciana Cabral Doneda. Rio de Janeiro: Renovar, 2008, p. 108.
} 
ABREU, Jacqueline de Souza. Conceitos de valor, interpretação, direito e política: críticas de Bernard Williams a Ronald Dworkin. Revista Eletrônica Direito e Política, Programa de Pós-Graduação Stricto Sensu em Ciência Jurídica da UNIVALI, Itajaí, v.13, n.2, $2^{\circ}$ quadrimestre de 2018. Disponível em: www.univali.br/direitoepolitica - ISSN 1980-7791

\section{REFERÊNCIAS DAS FONTES CITADAS}

ALMEIDA FILHO, José Carlos de Araújo. Direito Eletrônico ou Direito da Informática? Informática Pública vol. 7 (2): 11-18, 2005. Disponível em: <http://www.ip.pbh.gov.br/ANO7_N2_PDF/IP7N2_almeida.pdf>. Acesso em 22 set. 2017.

Ato de prevenção ao bullying na juventude. Disponível em: <https://osse.dc.gov/sites/default/files/dc/sites/osse/publication/attachments/O SSE\%20Bullying\%20Policy.pdf>. Acesso em: 25 mar. 2018.

BASTOS, Celso Ribeiro; MARTINS, Ives Gandra. Comentários à Constituição do Brasil. São Paulo: Saraiva: 2002.

BARROSO, Luis Roberto. Colisão entre Liberdade de Expressão e Direitos da Personalidade. Critérios de Ponderação: interpretação Constitucionalmente Adequada do Código Civil e da Lei de Imprensa. Revista de Direito Administrativo, Rio de Janeiro, v. 235, p. 19, jan. 2004. Disponível em: <http://bibliotecadigital.fgv.br/ojs/index.php/rda/article/view/45123/45026>. Acesso em: 10 out. 2017.

BEZERRA, Arthur Coelho; WALTZ, Igor. Privacidade, neutralidade e inimputabilidade da internet no brasil: avanços e deficiências no projeto do marco civil. Revista Eptic Online, v. 16, n. 2, p.157-171, maio/ago. 2014. Disponível em: <https://seer.ufs.br/index.php/eptic/article/viewFile/2276/1954 >. Acesso em: 25 set. 2017.

BOFF, Salete; FORTES, Vinícius Borges. A Privacidade e a Proteção dos Dados Pessoais no Ciberespaço como um Direito Fundamental: perspectivas de construção de um marco regulatório para o Brasil. Seqüência (Florianópolis), n. 68 , p. 109-127, jun. 2014.

BOLZAN DE MORAIS Jose Luis; NETO, Elias Jacob de Menezes. Quem é anônimo no mundo dos metadados? 0 problema do anteprojeto de lei para proteção de dados pessoais. Disponível em: <http://emporiododireito.com.br/tag/oproblema-do-anteprojeto-de-lei-para-protecao-de-dados-pessoais/\#_ftn4>.

Acesso em 22 set. 2017.

A "liquidez" da surveillance cabe nos limites da "solidez" do marco civil da Internet? Disponível em: <http://emporiododireito.com.br/aliquidez-da-surveillance-cabe-nos-limites-da-solidez-do-marco-civil-da-internetpor-jose-luis-bolzan-de-morais-e-elias-jacob-de-menezes-neto/>. Acesso em 22 set. 2017.

CALMON DE PASSOS, José Joaquim. Direito, poder, justiça e processo: julgando os que nos julgam. Rio de Janeiro: Forense, 2000.

CHOUKR, Fauzi Hassan. Código de Processo Penal - Comentários Consolidados e Crítica Jurisprudencial. Rio de Janeiro: Lumen Juris, 2016. 
ABREU, Jacqueline de Souza. Conceitos de valor, interpretação, direito e política: críticas de Bernard Williams a Ronald Dworkin. Revista Eletrônica Direito e Política, Programa de Pós-Graduação Stricto Sensu em Ciência Jurídica da UNIVALI, Itajaí, v.13, n.2, $2^{\circ}$ quadrimestre de 2018. Disponível em: www.univali.br/direitoepolitica - ISSN 1980-7791

CITRON, Danielle Keats. Cyber Civil Rights, 89 Boston University Law Review 81.

Compilado sobre aderência estadual à concepção de diplomas anticyberbullying em solo americano. Disponível em: <https://cyberbullying.org/bullying-laws>. Acesso em: 25 mar. 2018.

COSTA, Marco Aurélio Rodrigues. Crimes de informática. Disponível em: <http://www.jus.com.br/doutrina/crinfo.html.>. Acesso em: 05 jul. 2018.

D'AURIA, Jennifer. Cyberbullying Resources for Youth and Their Families. Journal of Pediatir Health Care, v. 28, n. 2, 2014.

FARIAS, Edilsom. Liberdade de expressão e comunicação: teoria e proteção constitucional. São Paulo: Revista dos Tribunais, 2004.

HABERMAS, Jürgen. Direito e Democracia: entre facticidade e validade. Rio de Janeiro: Tempo Brasileiro, 2003.

INIESTA, Javier Belda; SERNA, Francisco José Arenda. El Paradigma de la identidade: Hacia una regulación del mundo digital. Revista Forense, v. 422, jul./dez. 2015.

LUÑO, Antonio-Enrique Pérez. Teledemocracia, ciberciudadania y derechos humanos. Revista Brasileira de Políticas Públicas, Brasília, v. 4, n. 2, 2014.

MCCARTHY, Martha. Cyberbullying Laws And First Amendment Rulings: Can They Be Reconciled? Estados Unidos: Mississippi Law Journal: 2014.

MASON, K. L. Cyberbullying: A Preliminary Assessment for School Personnel. Psychology in the Schools, v. 45, n. 4, 2008.

MALDONADO, Maria Tereza. Bullying e Cyberbullying: o que fazemos com o que fazem conosco? São Paulo: Moderna, 2011.

Menina de 14 anos confessa ataques racistas a filha de Bruno Gagliasso. Disponível em: <http://g1.globo.com/jornal-nacional/noticia/2016/12/meninade-14-anos-confessa-ataques-racistas-filha-e-bruno-gagliasso.html $>$. Acesso em 25 set. 2017.

Ministério Público ouve suspeitos de racismo contra Maria Julia Coutinho. Disponível em: <http://g1.globo.com/sao-paulo/noticia/2015/12/ministeriopublico-ouve-suspeitos-de-racismo-contra-maria-julia-coutinho.html>. Acesso em 25 set. 2017.

MJ finaliza nova versão de anteprojeto sobre proteção de dados na internet. Disponível em <http://agenciabrasil.ebc.com.br/geral/noticia/201510/mj-finaliza-nova-versao-de-anteprojeto-sobre-protecao-de-dados-nainternet>. Acesso em 25 set. 2017. 
ABREU, Jacqueline de Souza. Conceitos de valor, interpretação, direito e política: críticas de Bernard Williams a Ronald Dworkin. Revista Eletrônica Direito e Política, Programa de Pós-Graduação Stricto Sensu em Ciência Jurídica da UNIVALI, Itajaí, v.13, n.2, $2^{\circ}$ quadrimestre de 2018. Disponível em: www.univali.br/direitoepolitica - ISSN 1980-7791

PINHEIRO, Reginaldo César. Os cybercrimes na esfera jurídica brasileira. Disponível em:<http://jus.com.br/revista/texto/1830/os-cybercrimes-na-esferajuridica-brasileira>. Acesso em: 05 jul. 2018.

Preso, criador do jogo de suicídio Baleia Azul fala em "limpeza da sociedade". Disponível em: <http://ultimosegundo.ig.com.br/mundo/2017-0510/baleia-azul.html>. Acesso em 25 set. 2017.

RODOTÀ, Stefano. A vida na sociedade da vigilância: a privacidade hoje. Tradução: Danilo Doneda e Luciana Cabral Doneda. Rio de Janeiro: Renovar, 2008.

ROWLAND, Diane. Privacy, Freedom of Expression and CyberSLAPPs: Fostering Anonymity on the Internet? International Review of Law Computers Carfax Publishing \&Technology, v. 17, n. 3, nov. 2003.

RUEDY, Matthew. Repercussions of a MySpace Teen Suicide: Should AntiCyberbullying Laws Be Created. Estados Unidos: North Carolina Journal of Law: 2008.

SARMENTO, Daniel. Livres e iguais. Estudos de Direito Constitucional. Rio de Janeiro: Lumen Juris, 2006.

Liberdade de expressão, pluralismo e o papel promocional do Estado. Revista Diálogo Jurídico, Salvador, n. 16, 2007.

SILVA, José Afonso da. Curso de direito constitucional positivo. 33 ed. São Paulo: Malheiros, 2015.

SUNSTEIN, Cass. R. Democracy and the problem of free speech. New York: The Free Press, 1995.

Supremo julga Lei de Imprensa incompatível com a Constituição Federal. Disponível em:

http://www.stf.jus.br/portal/cms/vernoticiadetalhe.asp?idconteudo $=107402>$. Acesso em 04 jul. 2018.

TEFFÉ, Chiara Spadaccini de; MORAES, Maria Celina Bodin de. Redes sociais virtuais: privacidade e responsabilidade civil. Análise a partir do Marco Civil da Internet. Revista Pensar, Fortaleza, v. 22, n. 1, jan./abr. 2017.

THOMPSON, Marcelo. Marco civil ou demarcação de direitos? Democracia, razoabilidade $\mathbf{e}$ as fendas na internet do Brasil. Revista de Direito Administrativo, Rio de Janeiro, v. 261, set../dez. 2012. Disponível em: <http://bibliotecadigital.fgv.br/ojs/index.php/rda/article/view/8856/7678>. Acesso em: 25 set.. 2017

VIANA, Marco Túlio apud CARNEIRO, Adeneele Garcia. Fundamentos de direito penal informático. Do acesso não autorizado a sistemas computacionais. Rio de Janeiro: Forense, 2003. 
ABREU, Jacqueline de Souza. Conceitos de valor, interpretação, direito e política: críticas de Bernard Williams a Ronald Dworkin. Revista Eletrônica Direito e Política, Programa de Pós-Graduação Stricto Sensu em Ciência Jurídica da UNIVALI, Itajaí, v.13, n.2, $2^{\circ}$ quadrimestre de 2018. Disponível em: www.univali.br/direitoepolitica - ISSN 1980-7791

SOUZA, Carlos Affonso e LEMOS, Ronaldo. Marco civil da internet: construção e aplicação. Juiz de Fora: Editar Editora Associada Ltda, 2016.

Mãe é condenada a pagar indenização por cyberbullying cometido pelo filho no Rio Grande do Sul. Disponível em: <https://oglobo.globo.com/brasil/mae-condenada-pagar-indenizacao-porcyberbullying-cometido-pelo-filho-no-rio-grande-do-sul-2984952>. Acesso em 09 ago. 2018.

TJRS. APELAÇÃO No 70031750094. Disponível em: < http://www1.tjrs.jus.br/site_php/consulta/consulta_processo.php?nome_comarc $\mathrm{a}=$ Tribunal+de+Justi\%E7a\&versao $=$ \&versao_fonetica $=1 \&$ tipo $=1$ \&id_comarca $=7$ 00\&num_processo_mask $=70031750094 \&$ num_processo $=70031750094 \&$ codEme nta $=3620419 \&$ temIntTeor $=$ true $>$. Acesso em 09 ago. 2018.

Dona de grupo de WhatsApp é condenada por permitir bullying. Disponível em: <https://www1.folha.uol.com.br/cotidiano/2018/07/dona-de-grupo-dewhatsapp-e-condenada-por-permitir-bullying.shtml>. Acesso em 09 ago. 2018.

TJSP. APELAÇÃO No 1004604-31.2016.8.26.0291. Disponível em: <https://www.conjur.com.br/dl/administrador-grupo-whatsapp-condenado.pdf>. Acesso em 09 ago. 2018.

LAMY, Marcelo. Conflitos dogmáticos da proteção penal do ambiente e da ordem econômica. In Revista Brasileira de Direito Constitucional - RBDC n. 11 - Jan/Jun 2008. Disponível em: <http://www.esdc.com.br/RBDC/RBDC-11/RBDC11-013-Marcelo_Lamy.pdf>. Acesso em 09 ago. 2018.

Recebido em: 09/08/2018

Aprovado em: 28/08/2018 